\title{
Measuring the Low-Income Earner on Housing Access in Urban Areas of Indonesia and Malaysia
}

\author{
Mazliza Mohamad ${ }^{1}$, Ricco Survival Yubaidi², Safinaz Mohd Hussein ${ }^{3}$, Rahmah Ismail ${ }^{4}$, \\ Suzanna Mohamed Isa ${ }^{5}$, Saidatul Nadia Abdul Aziz ${ }^{6}$ \\ ${ }^{1}$ Faculty of Law, Universiti Kebangsaan Malaysia, Malaysia.E-mail: mazliza@ukm.edu.my \\ 2 Faculty of Law, Universiti Kebangsaan Malaysia, Malaysia.E-mail: riccoyubaidi@gmail.com \\ ${ }^{3}$ Faculty of Law, Universiti Kebangsaan Malaysia, Malaysia.E-mail: finaz@ukm.edu.my \\ ${ }^{4}$ Faculty of Law, Universiti Kebangsaan Malaysia, Malaysia. E-mail: irahmah@ukm.edu.my \\ ${ }^{5}$ Faculty of Law, Universiti Kebangsaan Malaysia, Malaysia.E-mail: zie@ukm.edu.my \\ ${ }^{6}$ Faculty of Law, Universiti Kebangsaan Malaysia, Malaysia.E-mail: nadia_aziz@ukm.edu.my
}

\begin{abstract}
The ratio between the increased demand and limited land makes affordable housing in urban areas more difficult to accommodate. Indonesia and Malaysia, as populous countries, face problems related to housing access, especially for low-income earners in urban areas. The research was undertaken for two reasons. First, problems related to housing access for low-income earners in urban areas should be solved as soon as possible. Second, it is necessary to conduct a study in order to analyze and compare these two countries in measuring low-income earners on housing access in urban areas. To this end, the normative legal approach was applied. The materials used in this study were relevant statutes, rules, regulations, journals, articles, thesis, seminar papers, and electronic materials. The result showed that the fulfillment of housing access highly depends on the state's developmental goals. It is also associated with principles of development that each country adheres to. The government is expected to provide accurate data in measuring low-income earners on housing access. Identification of beneficiaries by combining income classification and ability to housing access may facilitate policymakers with ease when taking affirmative measures. It is necessary to suggest initiative collaboration involving academicians, business sectors, community, and government (ABCG) in Indonesia and Malaysia to provide adequate housing in urban areas.
\end{abstract}

Keywords: Housing Access; Housing Affordability; Housing Policy; Low-income Earners

\section{Introduction}

Housing access is pivotal for enhancing life quality, especially for low-income earners in urban areas. Indonesia and Malaysia share some similarities in facing this issue, where Price to Income Ratio (PIR) in Indonesia is 22.01 and PIR in Malaysia is $9.92^{1}$. The people's low affordability is one of the factors that hinders demands on housing from being properly addressed. This is worsened by the fact that house prices keep increasing and going far beyond the community's average income. A question then arises, does the fulfillment of housing access belong to the individual or is it the States' responsibility? Another question is, how the State defines its role in identifying people who need housing

$\begin{array}{cccccc}1 & \text { Numbeo. (2021). Asia: Property Prices Index by Country } 2021 .\end{array}$


access while their functions is also to provide flexibility and balance in the property industry for public interest.

Discussion on the provision of affordable housing is endless. Up to now, the meaning and definition of affordable housing is still a challenge and debate among the public, especially for housing researchers. To make it easier to understand the concept of affordable housing, there are things that must be mutually agreed upon and defined in advance, such as the definition or characteristics of affordable housing. ${ }^{2}$ If we see in United Kingdom and the United States, affordability is often expressed in terms of "affordable housing." Affordability is not a characteristic of housing, it is a relationship between housing and people. For some people, all houses are affordable, no matter how expensive it is; whereas for others, no housing is affordable unless it is free. ${ }^{3}$

Discussing on housing access is not a new issue for Indonesia and Malaysia. Several discourses, research, and legal products have been issued to address the fulfillment of housing access. The Indonesian government handles this issue through its National Medium-Term Development Plan, while the Malaysian government has The Malaysia Plan (MP). Both programs involve discussions related to the fulfillment of housing access in every development plan every five years. It is necessary to evaluate the underlying problems of acceleration of housing access fulfillment.

If we look at the reference from UN HABITAT ${ }^{4}$, it explains that international human rights law recognizes everyone's right to an adequate standard of living, including adequate housing. The right to adequate housing contains entitlements. These entitlements include: (1) Security of tenure, (2) Housing, land and property restitution, (3) Equal and non-discriminatory access to adequate housing (4) Participation in housing related decision-making at the national and community levels. For housing to be adequate, it must, at a minimum, meet the following criteria:

a. Security of tenure: housing is not adequate if its occupants do not have a degree of tenure security which guarantees legal protection against forced evictions, harassment and other threats.

b. Availability of services, materials, facilities and infrastructure: housing is not adequate if its occupants do not have safe drinking water, adequate sanitation, and energy for cooking, heating, lighting, food storage or refuse disposal.

c. Affordability: housing is not adequate if its cost threatens or compromises the occupants' enjoyment of other human rights.

d. Habitability: housing is not adequate if it does not guarantee physical safety or provide adequate space, as well as protection against cold, damp, heat, rain, wind and other threats to health and structural hazards.

e. Accessibility: housing is not adequate if the specific needs of disadvantaged and marginalized groups are not taken into account.

\footnotetext{
2 Sulaiman, N., Baldry, D., and Ruddok, L. (2005). "Can Low-Cost Housing in Malaysia be Considered as Affordable Housing" European Real Estate Society Conference: Dublin 8

3 Tighe, J.R., and Mueller, E.J. (2013). The Affordable Housing Reader. Abingdon: Routledge, p. 96

${ }^{4}$ Office of the United Nations High Comissioner for Human Rights, The Right to Adequate Housing, Fact Sheet No. 21/Rev.1
} 
f. Location: housing is not adequate if it is cut off from employment opportunities, health-care services, schools, childcare centres and other social facilities, or if located in polluted or dangerous areas.

g. Cultural Adequacy: housing is not adequate if it does not respect and take into account the expression of cultural identity.

Developments that are less attentive to the low-income earners' interests make these people face difficulty to own a proper, affordable house. Besides, the affordable housing program should not only target those categorized as low-income earners given that many people in the middle economic class also find it difficult to own a house. The key to solving these people's problem is the successful criteria identification of the program beneficiaries. Therefore, the present study attempts to focus more on the problems related to the fulfillment of housing access as a person's right, especially individuals categorized as low-income earners.

The present study aims to identify the problems related to housing access for low-income earners in urban areas and to conduct a study to analyze and compare both Indonesia and Malaysia in measuring the low-income earners in housing access from a legal perspective. Regarding the limitations of the research, this study only examines the literature review sources of the research that focused on Java-Bali Indonesia and Peninsular Malaysia. This study is expected to depict the development of the regulation and measuring the low-income earner on housing access, who needs it, what types of programs could be effective, which is associated with the challenges and obstacles met.

\section{Community Based Low-income Earners in Indonesia}

Indonesia is the most populous Southeast Asian country. Its economy is the largest in the region. ${ }^{5}$ According to the data from Badan Pusat Statistik ${ }^{6}$, this country spans an area of 1,916,906.77 km2 and has 16,056 islands with approximately 268 million citizens. Indonesian government's vision for 2045 is to be a sovereign, fair and prosperous country, and to move from middle- to high-income status. An inclusive, efficient social protection system is essential to achieve that. ${ }^{7}$

Article $28 \mathrm{H}$ paragraph (1) of the 1945 Constitution asserts that each person has a right to a life of well-being in body and mind, to a place to dwell, to enjoy a good and healthy environment, and to receive medical care. Furthermore, Article $28 \mathrm{H}$ paragraph (2) explains that each person has their right to facilities and special treatment to get the same opportunities and advantages in order to reach the equality and justice.

If we see in Article 3 of Act. No. 5 of 1960 concerning Basic Agrarian Law (BAL), it is stated that the relationship between the Indonesian nation and earth, water, and airspace within the territory of the Republic of Indonesia is eternal. The state, as the power organization, receives a mandate from the people to regulate, manage, and determine

5 Hossain, A.A. (2012). Macroeconomic and Monetary Policy Issues in Indonesia. Abingdon: Routledge, p. xxiii

${ }^{6}$ Badan Pusat Statistik. (2021). Statistik Indonesia 2021, Badan Pusat Statistik, p. 10

7 The World Bank. (2019). "Indonesia Economic Quarterly, Investing in People”, p. 56 
the legal relationships related to earth, water, and airspace, including the natural riches therein.

However, Indonesia has experienced a shift of natural resources control when natural resources are privatized by capitalists, turning the sources of the state's natural resource into commodity objects. As a result, 2020-2024 medium-term development plan reports that only $54.1 \%$ of Indonesian households live in livable houses. Another data published by Badan Pusat Statistik showed that 3 out of 10 Indonesian households buy a house through 'Kredit Pemilikan Rumah/KPR' (Housing Ownership Loan), with $47.78 \%$ of them pay installments for $11-15$ years.

Access to housing is crucial since it supports the fulfillment of other rights, including religious, education, and cultural rights. Indonesia does not regulate a unified standard on income level in identifying its citizens. However, in housing access, the government recognizes the term 'Masyarakat Berpenghasilan Rendah' (low-income earners). Article 1 paragraph (24) of Act. No. 1 of 2011 concerning Housing and Residential Area defines low-income earners as individuals with limited purchasing power so that they need to receive the government's support to purchase a house. Considering the statistical data presented above, low-income earners should not only be defined as those who are living on poverty line because the fact shows that people who are deemed above the poverty line also find it difficult to obtain housing access.

Through existing regulations, requirements to obtain easiness to housing access by Regulation of Minister of Public Works and Public Housing no. 10/PRT/M/2019 on Criteria of Low-Income Earner and Requirement of Easiness to Obtain House for Low Income Earners, have been regulated as follows:

a. An Indonesian Citizen

b. Registered as a citizen in a regency/city.

c. Have never received any housing-related aid.

However, the criteria above are considered to provide an unclear description of beneficiaries since each citizen faces unique cases and problems. Low-income earners are different from a poor citizen who lives under the poverty line. Low-income earners, based on their ability to access housing ownership, could be divided into three segments as follow: 8

a. Low income earners who already have a land or a house but not able to build or repair.

b. Low income earner who can afford to buy a house but the ability to pay installments is low.

c. Low income earners who are not able to buy a house.

The form of government support for each of the segments mentioned above is certainly different. For low-income earner who cannot afford a house at all, the government can provide simple rental flats (RUSUNAWA) and 'RUMAH SWADAYA' for low-income people who already own land or a house. For low-income earner who can afford to buy a house

\footnotetext{
${ }^{8}$ Direktorat Jenderal Anggaran Kementerian Keuangan. (2015). Peranan APBN Dalam Mengatasi Backlog Perumahan Bagi Masyarakat Berpenghasilan Rendah (MBR), p. 7
} 
but the ability to pay the installment 'Kredit Pemilikan Rumah' is low, the government provides subsidies in the form of a Housing Financing Liquidity Facility (FLPP).

Regarding these three segments, Act. No. 1 of 2011 has guaranteed easiness through its Article 54, which regulates the easiness of developing and acquiring a house. Further, Article 126 of Act. No. 1 of 2011 stipulates that the central and local government should provide easiness related to funding for developing and acquiring a house. However, this Act could not work optimally if the property price keeps increasing while the government has not finished identifying the beneficiaries of the easiness.

Article 13 paragraph (f) and (g) of Act. No. 1 of 2011 obliges the government to allocate development funds to support housing programs and to facilitate the provision of houses for low-income earners. When the classification of low-income earners is too low, the government will find it difficult to execute the program because low-income classification is incomparable with increasing house prices. Otherwise, when the classification of lowincome earners is too high, those with high income stands a greater opportunity to follow the program. ${ }^{9}$ Equal development could overcome gap among the community. Efforts in fulfilling needs of housing could be realized through developing apartments. ${ }^{10}$ However, in Indonesia, the apartment is not popular among the community as people view apartment as less comfortable due to limited space. Indonesian citizen tends to prefers terrace house. ${ }^{11}$

Considering this phenomenon, an initiative collaboration of academicians, business sectors, community, and government $(A B C G)$ is expected to bring new hope of housing access for low-income earners. ABCG collaboration could develop community-based housing as an alternative to solve housing backlog. Involving the community may bridge academicians, business sectors, and the government to identify the low-income earners. This is important given that the majority of Indonesian people work in informal sectors. Meanwhile, financing institutions require some criteria for their debtors in order to ensure that they meet 5C (Character, Capacity, Capital, Collateral, and Condition). This issue is worsened by the fact that only $60 \%$ of Indonesian people possess a bank account. $^{12}$

However, Indonesian people characteristic who like to gather in a community can be used to bridge those who are not able to access banking facilities individually. Communitybased housing development could be carried out through guidance, starting from creating a group, establishing a partnership with a bank, releasing land, applying for the program, building the house, to repaying the installment.

9 Kementerian Komunikasi dan Informatika Republik Indonesia. (2020). Akselerasi Penyediaan Rumah Bagi Masyarakat Berpenghasilan Rendah, https://kominfo.go.id/content/detail/29464/akselerasipenyediaan-rumah-bagi-masyarakat-berpenghasilan-rendah/O/berita

${ }^{10}$ Kurniati, N. (2014). Pemenuhan Hak atas Perumahan dan Kawasan Permukiman yang Layak dan Penerapannya menurut Kovenan Internasional tentang Hak-hak Ekonomi, Sosial dan Budaya di Indonesia, Padjajaran Jurnal Ilmu Hukum, p. 91

11 Indraningrum, L. (2016). "Rencana Kepemilikan Rumah Bagi Masyarakat Berpenghasilan Rendah (Studi Kasus Kelurahan Tanjungmas Kota Semarang)", Jurnal Teknik Sipil \& Perencanaan, 1(18), p. 6

12 Al Hikam, H.A. (2019). OJK Sebut Cuma 60\% Orang RI Punya Rekening Bank, https://finance.detik.com/moneter/d-4522143/ojk-sebut-cuma-60-orang-ri-punya-rekening-bank 
The collaboration of ABCG should be enhanced to reach the community to understand the detail of beneficiaries of low-income earners housing facilities. It is expected that community-based development can provide a check-and-balance mechanism between the beneficiaries and the interesting parties. Furthermore, data related to the beneficiaries of the housing program for low-income earners should be properly managed so that the government possess valid, measurable data on the needs of housing access in the future.

\section{Income Classifications by Household in Malaysia}

Malaysia consists of two distinct geographical area separated by the South China Sea, were Peninsular Malaysia in the west and East Malaysia in the east. It is located in the center of Southeast Asia, being an extension of the Asian land mass as well as part of the wider Malay Archipelago. ${ }^{13}$ With a population of 32.5 million, Malaysian citizens still find it difficult to obtain access to housing. The rate of increase in house prices has differs across housing types and location. Between 2000 and 2016, house prices in Malaysia have more than doubled. ${ }^{14}$

In Malaysian housing industry, one of the housing problems includes abandoned housing projects. ${ }^{15}$ Such problem arises as a result of a number of factors, including private developers, housing contractors, the government or authorities, financial institutions, economic crisis and politics. ${ }^{16}$ On the other hand, the issues in affordable housing have increased in recent years, indicating the impact of government measures owing to weaknesses in the design, sustainability and implementation of public housing schemes. ${ }^{17}$ Ministry of Housing and Local Government is responsible for the housing policy. Under this ministry, there are several departments that are directly involved in the implementation, approval of public housing development and also providing the guidelines and planning standards for the State and Local Government. ${ }^{18}$

Access to housing is a basic need for every community. Governments need to ensure that individuals have equal opportunity to own or lease homes. Up to now, the need and access to housing is still limited, especially for low-income groups in urban areas. The private sector need to continue providing affordable houses for sale or rental for the low-

${ }^{13}$ Swee-Hock, S. (2007). The Population of Malaysia, Singapore: Institute of Southeast Asian Studies Publishing, p. 1

${ }^{14}$ Khazanah Research Institute. (2019). "Rethinking Housing: Between State, Market and Society", Kuala Lumpur: Khazanah Research Institute, p. 16

${ }_{15}$ Md Dahlan, N.H. (2011). Comparative Housing Sale and Purchase Agreements Under the Malaysia, Singapore, and New South Wales Housing Laws, Kedah: Universiti Utara Malaysia Press, p. 1

${ }^{16}$ Mumin, M.H., and Zainol, F.A. (2016). "Causes of Abandoned Housing Projects in Malaysia - The Stakeholders Views, Asian Journal of Knowledge Management, p. 18

17 Bilal, M., Meera, A.K.M., and Razak, D.A. (2018). "Issues and Challenges in Contemporary Affordable Public Housing Schemes in Malaysia,

18 United Nations Human Settlements Programme. (2008). The Role of Government in the Housing Market, The Experience from Asia, Nairobi: United Nations Human Settlements Programme (UN-HABITAT), p. 62 
income group, the disabled, senior citizens and single mothers. ${ }^{19}$ In relation to lowincome earners, each State has a housing division department that monitors implementation of low cost housing and low medium cost projects developed by the government and private sectors.

In Malaysia, the definition of low-cost housing varies from state to state. Under the Federal Constitution, land is a State matter. ${ }^{20}$ It is vital for states to evaluate the number of households that qualify for their social housing sector based on local conditions. Needbased assistance is already differentiated at the state level and, under the current framework, states can decide their own qualifying criteria. However, it is not clear whether the eligibility criteria are tied to the state income level. ${ }^{21}$

Malaysians are categorized into three different income groups - Top 20 percent (T20), Middle 40 per cent (M40), and Bottom 40 per cent (B40). The T20 group is defined as the median household income of at least RM13,148 while the M40 and B40 group's median household income have moved their bars up to RM 6,275 and RM 3,000 respectively, according to the research findings of the Household Income and Basic Amenities Survey 2019 carried out by the Statistic Department. ${ }^{22}$ However, as occurs in Indonesia, whether or not the basis to fulfill the housing needs have been fit and measurable when using income classification per household is still questioned. The question arises because citizens have different characteristics in fulfilling their housing needs, let alone most of them prefer to own a house, not rent. In Malaysia, it was found that those who have ability to buy a house do not have cost to keep. Different actions to take related to housing access through purchasing or leasing scheme becomes more complex for the government. The government has limited ability in relation to cost to keep. Besides, people's income is also affected by cost of other needs, such as medical care, foods, and basic amenities.

Low-cost housing in Malaysia aims specifically to improve the life quality of low-income earners. ${ }^{23}$ Malaysia has experienced rapid urbanization, bringing much prosperity in the urban areas, however there is another side of the city where the urban poor and B40 lives, which needs urgent intervention. ${ }^{24}$

${ }^{19}$ National Housing Department Ministry of Housing and Local Government. (2016). National Housing Policy, p. 82

20 United Nations Human Settlements Programme. (2008). The Role of Government in the Housing Market, The Experience from Asia, Nairobi: United Nations Human Settlements Programme (UN-HABITAT), p. 62

${ }^{21}$ Khazanah Research Institute. (2019). "Rethinking Housing: Between State, Market and Society", Kuala Lumpur: Khazanah Research Institute, p. xii

22 Leong, S.K. (2019). A Look at Every Aspect of Home Ownership. https://www.nst.com.my/property/2019/02/460076/look-every-aspect-home-ownership

23 Zaid, N.S.M., and Graham, P. (2011). "Low-cost Housing in Malaysia: a Contribution to Sustainable Development?", $1^{\text {st }}$ International Postgraduate Conference on Engineering, Designing and Developing the Built Environment for Sustainable Wellbeing, p. 84 http://dx.doi.org/10.13140/RG.2.1.2715.9120

24 Jayasooria, D. (2020). Localizing SDGs among B40 Neighborhoods in Klang Valley, Malaysia: Challenges, Possibilities, and Lessons Drawn from the Urban Grassroots, Siri Kertas Kajian Etnik UKM, p. 20 
Key housing challenge in Malaysia is mostly related to mismatch in demand and supply for affordable housing. Supply side initiatives need more attention in Malaysia, especially areas related to cost of effective housing development measures, maintenance and operation cost, and regulation related matters. ${ }^{25}$ In addition to mismatch in demand and supply, there is also mismatch in desire and supply, which can be viewed from the decision that low income earners who work in the city could not afford to live in urban area, thus making them live far from their workplace and face risk of longer distance and high transportation cost.

In the $11^{\text {th }}$ Malaysia Plan (11MP), accesses to housing have been discussed. It is stated that the government will continue to uplifting B40 households towards a middle-class society. Government also ensure that affordable homes are available to B40 households. One of the programs mentioned in $11 \mathrm{MP}$, are special interest rate loans, with a 10 -year moratorium on sale of the property, will be provided to B40 households to enable them to own houses. In order to do that, the level of financial literacy and financial management capability from an early age will also help to prevent high indebtedness among B40 households. Hence, data transparency and proper classification identification of B40 in Malaysia is important to determine the beneficiaries of access to housing.

However, this classification needs a number of improvements so that it can be integrated with the needs of housing access. Besides, there must be a clear definition of affordable housing in Malaysia because it may be different for each individual or income group. Affordable houses should be built within the people's affordability, which focuses on low and medium-income groups. Moreover, government should revise the ceiling price for affordable housing. ${ }^{26}$

\section{Housing Policies Optimisation for Low-income Earners}

Since issued in 12 January 2011, Indonesia has already had a law that regulates housing and residential area, i.e., Act. No. 1 of 2011. This law represents the state's effort and responsibility of protecting Indonesian people through the provision of housing and residential area. Article 5 of Act. No. 1 of 2011 concerning Housing and Residential Area stipulates that the state is responsible for the provision of housing and residential area, in which the guidance is carried out by the government. Guidance, as meant in Article 5 involves planning, regulating, controlling, and monitoring.

In line with that responsibility, Article 105 paragraph (1) of Act. No 1 of 2011 Housing and Residential Area stipulates that the central and local governments, based on their authority, are responsible for the availability of land to build houses and residential areas. Housing access is a mandate the state must fulfill. In its implementation, central and local government can use a set of policies and other instruments for affirmation, such as obliging the private developers to build non-commercial houses in addition to their private/commercial houses, etc. Considering the current number of private housing,

25 Samad, D., Zainon, N., Mohd Rahim, F.A., Lou, E., and Abd Karim, S.B. (2016). "Malaysian Affordability Housing Policies Revisited", MATEC Web of Conference, p. 8

${ }^{26}$ Jamaluddin, N.B., Abdullah, Y.A., and Hamdan, H. (2016). "Encapsulating the Delivery of Affordable Housing: An Overview of Malaysian Practice, MATEC Web of Conference, p. 7 
there should be already many non-commercial houses built by private developers to fulfill such an obligation. The regulation obliges property developers to provide a public apartment of at least $20 \%$ of the commercial houses they have built. However, data on non-commercial houses are still limited, resulting in difficulty to assess the result or achievement of this policy. Although the regulation applies generally to the type of housing built by developers, the regulatory article in Act. No. 20 of 2011 only stipulates about apartments.

The government, which holds a supervisory function, should actively collect the data related to non-commercial houses built by the developer, whether or not it meets the requirement and standard for the beneficiaries (i.e., low-income earners). Further, innovation can also be made by the regional governments by obliging property business sectors (e.g., hotels) to contribute to the development of the residential area for lowincome earners. Ease of doing business and investment should come along with the business' contribution to the regional government.

An obstacle that should be faced by home buyers is the fact that most low-income earners work in the informal sector with uncertain income. To date, the funds available in banking and financing institutions is categorized as short-term funds and expensive, while house financing needed by low-income earners should be long-term and inexpensive. Accordingly, it is necessary to have a special mechanism to turn these nonbankable low-income earners into bankable individuals. ${ }^{27}$

Indonesian government, through Minister of Home Affair, has issued Circular Letter no. $648 / 1062 / S J$ regarding acceleration of housing development for low income earners. Such acceleration includes three instructions consisting of removing required permits, permit merges, and acceleration of permit processing duration. These instructions are expected to minimize complains from the property developers who complain about timeconsuming and costly permit processing. For low income earners, this circular letter may not give significant effect, considering that they need innovative, rational, and affordable funding scheme to buy a house.

Housing loan requires thoughtful consideration. As stated above, since housing loan for low income earners should be long-term and inexpensive, both countries (i.e., Indonesia and Malaysia) needs to consider the urgency of a financing/banking institution that specifically aims to serve people with characteristics of low-income earners. In Thailand, there is a bank called National Housing Bank, an apex financial institution for housing. The study conducted by Jeevanandam et al, ${ }^{28}$ found that National Housing Bank enhanced the affordability of housing facilities to the urban and rural poor. National Housing Bank predominantly regulates the entire financial system of housing by its regulations. Further studies and consideration are necessary to find out the effectiveness of such a bank when it is applied in Indonesia and Malaysia.

27 Mangeswuri, D.R. (2016). “Kebijakan Pembiayaan Perumahan Melalui Fasilitas Likuiditas Pembiayaan Perumahan (FLPP)", Jurnal Ekonomi \& Kebijakan Publik, 7(1), p. 93

28 Jeevanandam, C., and Veerappan, M. (2019). "A Study on the Role of National Housing Bank (NHB) in Housing Finance, Asian Journal of Managerial Science, p. 95 
In Malaysia, housing strategies and program outlined in the housing sector are stipulated in the National Housing Policy (NHP) which is drafted every five years. ${ }^{29}$ One of the issues faced by Malaysia concerns with access and the community's ability in choosing dwelling. The affordability problem arises because of housing being too expensive. ${ }^{30}$ For a country with huge territory like Indonesia, attempts to provide access and affordability is carried out by opening new areas for dwellings. However, in Malaysia, due to smaller area (compared to Indonesia's), the government pays special attention to the regulation, organizing availability, and the spatial plan to adjust to the state's goals.

A clear and measurable approach is needed to reduce poverty in Malaysia in terms of definitions, measurement, policies and programs. ${ }^{31}$ Based on Ministry of Housing and Local Government definition, housing provision in Malaysia are divided into several categories according to selling price, namely high, medium, low medium and low-cost housing. ${ }^{32}$ Housing affordability indexes are important for stakeholders (e.g. the government, banks and developers) to determine the affordability of the housing market and help them take corrective measures to ensure affordability of housing in the market. ${ }^{33}$

Affordable housing is a Federal as well as a State matter. According to the Federal Constitution of Malaysia, at the Federal level, the Federal government is responsible of providing grants or loans and technical expertise to undertake the development of affordable housing, while at the State level, the government is responsible in identifying suitable location for affordable housing project. ${ }^{34}$

Consistent and harmonious laws and regulations are important to ensure the fulfillment of access to housing is developed in an orderly, timely manner and is carried out according to established specifications. The fulfillment of housing access will be affected and disrupted when the existing laws, policies and regulations overlap and are not implemented effectively. In the Malaysian context, until now there is no 'umbrella act' related to housing and residential area. The presence of this law can provide legal guarantees and certainty for all interested parties.

Since housing ownership has not emerged as a popular solution possibly due to limited land availability, rent option could be viewed as a wise decision. Considering that urban and industrial area in Malaysia have offered a range of options of house rent, it is also

${ }^{29}$ Ministry of Housing and Local Government. (2011). "Housing in the New Millenium - Malaysian Perspective", https://ehome.kpkt.gov.my/index.php/pages/view/297

30 Mat Asek, B. (2012). "Implications of the People's Housing Programme Policy". Journal of Administrative Science, 9(2), p. 45.

${ }^{31}$ Nair, S., and Sagaran, S. (2015). "Poverty in Malaysia: Need for a Paradigm Shift". Institutions and Economies, 7(3), p. 111

32 Shuid, S. (2010). "Low Income Housing Allocation System in Malaysia: Managing Housing Need for the Poor". 22 $2^{\text {nd }}$ International Housing Research Conference, p. 4

33 Zamri, A.M. (2019). "Homeownership Gaps Among the Middle Income Group in Malaysia”, Journal of Science, Technology and Innovation Policy (JOSTIP), 5(2), p. 60

34 Woo, K.H. (2018). "Affordable Housing Policy in Penang State of Malaysia, Global Encyclopedia of Public Administration, Public Policy and Governance, p. 2 https://doi.org/10.1007/978-3-319-31816$5 \quad 3671-1$ 
necessary for the Malaysian government to issue a Residential Tenancy Act in order to protect both the landlord and tenant under residential tenancy agreements.

Income classifications play a critical role determining the beneficiaries of welfare provisions in Malaysia. At present, most forms of social welfare aid are disbursed to households in the B40. ${ }^{35}$ In addition to social welfare aid program, the increase of salaries can directly improve the ability to own affordable housing. However, income growth on the other hand depends on too many factors and it is difficult to improve in a short period of time. ${ }^{36}$ It serves as a challenge for the government to see whether the existing law manages to decrease disparity between housing prices and increase of salaries among the community in B40.

Research shows that almost half of the housing finance schemes require high costs, while the general public need a low or medium home financing scheme. ${ }^{37}$ The availability of affordable housing, especially for low-income earners, must be recognized, especially for housing developers as housing providers. Access to affordable housing can be achieved at a low cost even though it still meets the eligibility standards. To achieve objective of national housing policy in Malaysia, it is important for the government to provide a good quality house so that they can live in a comfortable way. ${ }^{38}$

\section{Conclusion}

A policy can provide benefits and a significant impact if we make the right properly. As law functions to protect the public interest, the provision of housing access should be thoughtfully considered not only for the current generation but also for the future generation. Providing housing access, especially for low-income earners is not an easy business since it requires multidimensional and cross-factor solutions. The increasing birthrate due to better health quality, environment, food, and access to medical facilities also contribute to the increasing population and adequate housing needs. This study examines the literature sources of the research that focused on housing access in urban areas specifically in Java-Bali Indonesia and Peninsular Malaysia. Housing Access for lowincome earners in urban areas should be solved as soon as possible. Researchers hope to give practical and theoretical implications by conducting a study in order to analyze and compare these two countries in measuring low-income earners on housing access in urban areas.

\footnotetext{
35 Joshi, D. (2020). "Rethinking Malaysia's Income Reclassification not B40, but B40", Research for Social Advancement Brief, 2(3), p. 7

36 Zamri, A.M. (2019). "Homeownership Gaps Among the Middle-Income Group in Malaysia", Journal of Science, Technology and Innovation Policy (JOSTIP), 5(2), p. 60

37 Tobi, S.U.M., Jasimin, T.H., and Rani, W.N.M.W.M. (2020), "Overview of Affordable Housing from Supply and Demand Context in Malaysia, The $1^{\text {st }}$ International Conference on Urban Design and Planning, p. 6, doi: https://doi.org/10.1088/1755-1315/409/1/012010

38 Mohd-Rahim, F.A., Zainon, N., Sulaiman, S., Lou, E., Zulkifli, N.H., and Ayob, M.F. (2019). "Factors Affecting the Ownership of Low-cost Housing for Socio-Economic Development Malaysia", Journal of Building Performance. p.14
} 
The state's strategy and role in fulfilling people's access to housing ownership highly depend on the state's development goal. It is also associated with principles/ideology of development that each country adheres to. In measuring the low-income earner on adequate housing access, Malaysia categorizes based on three different income classification groups, namely Top 20 percent (T20), Middle 40 percent (M40), and Bottom 40 percent (B40). Income classifications play a critical role in determining the beneficiaries of welfare provisions in Malaysia. While, Indonesia categorizes based on ability to access, namely (a) Low-income earner who already have a land or a house but not able to build or repair, (2) Low-income people who can afford to buy a house but the ability to pay installments is low, and (3) Low-income earners who are not able to buy a house.

Currently, Indonesia has a legal basis for housing-related regulation namely the Act. No. 1 of 2011 concerning Housing and Residential Area, while Malaysia needs to immediately regulate the Act concerning Housing and Residential Area. Regulating the housing access through an Act can be effective with the presence of supervision and enforcement that are carried out by clean, accountable, and transparent institutions. There is a need for an accurate measurement to identify people and families who need specific intervention from the government on housing access in urban areas. Identification of beneficiaries based on analysis of measurement combining income classification and ability to housing access may facilitate policymakers with ease during taking affirmative measures. It is necessary to suggest a collaboration initiative involving academicians, business sectors, community, and government (ABCG) in Indonesia and Malaysia to provide adequate housing in urban areas.

\section{Acknowledgements}

This work was supported by the FRGS grant "Pembinaan Garis Panduan Perumahan B40 Untuk Meningkatkan Akses Kepada Perumahan B40 Dan Garis Panduan Pembangunan Perumahan B40 Kepada Pemaju Dalam Membangunkan Perumahan Bagi Golongan B40" Number FRGS/I/2019/SSI10/UKM/02/2.

\section{References}

Al Hikam, H. A. (2019, April 23). OJK Sebut Cuma 60\% Orang RI Punya Rekening Bank, Retrieved from https://finance.detik.com/moneter/d-4522143/ojk-sebut-cuma-60orang-ri-punya-rekening-bank

Asek, B. M. (2012). Implications of the People's Housing Programme Policy, Journal of Administrative Science, 9(2), Retrieved from https://jas.uitm.edu.my/images/ 2012 DEC/5.pdf

Bilal, M., Meera, A. K. M., \& Razak, D. A. (2019). Issues and Challenges in Contemporary Affordable Public Housing Schemes in Malaysia: Developing an Alternative Model, International Journal of Housing Markets and Analysis, 12(6), https://doi.org/10.1108/IJHMA-11-2018-0091

Direktorat Jenderal Anggaran Kementerian Keuangan. (2015). Peranan APBN Dalam Mengatasi Backlog Perumahan Bagi Masyarakat Berpenghasilan Rendah (MBR), Retrieved from http://www.anggaran.kemenkeu.go.id/api/Medias/d5d98b36-3ed8- 
4b9f-9d95-b95a6e8878cf

Hossain, A. A. (2012). Macroeconomic and Monetary Policy Issues in Indonesia, Abingdon: Routledge

Indrianingrum, L. (2016). Rencana Kepemilikan Rumah Bagi Masyarakat Berpenghasilan Rendah (Studi Kasus Kelurahan Tanjungmas Kota Semarang). Jurnal Teknik Sipil Dan Perencanaan, 18(1), 15-20. https://doi.org/10.15294/jtsp.v18i1.6690

Ismail, D. S. (2019). Rethinking Housing : Between State, Market and Society.

Jamaluddin, N. B., Abdullah, Y. A., \& Hamdan, H. (2016). Encapsulating the delivery of affordable housing: An overview of Malaysian practice. MATEC Web of Conferences, 66, 1-8. https://doi.org/10.1051/matecconf/20166600047

Jayasooria, D. (2020). "Localizing SDGs among B40 Neighborhoods in Klang Valley, Malaysia: Challenges, Possibilities, and Lessons Drawn from the Urban Grasroots, Siri Kertas Kajian Etnik UKM

Jeevanandam, C., \& Veerappan, M. (2019). A Study on the Role of National Housing Bank ( NHB ) in Housing Finance. 8(1), 93-95, Retrieved from https://www.trp.org.in/wpcontent/uploads/2019/07/AJMS-Vol.8-No.1-January-March-2019-pp.93-95.pdf

Joshi, D. (2020). Rethinking Malaysia's Income Reclassification. (2), Retrieved from https://refsa.org/wp-content/uploads/2020/03/Final Income-Reclassification B20.pdf

Kementerian Komunikasi dan Informatika RI. (2020, September 17). Akselerasi Penyediaan Rumah Bagi Masyarakat Berpenghasilan Rendah, Retrieved from https://kominfo.go.id/content/detail/29464/akselerasi-penyediaan-rumah-bagimasyarakat-berpenghasilan-rendah/0/berita

Khazanah Research Institute. (2019). Rethinking Housing: Between State, Market and Society", Kuala Lumpur: Khazanah Research Institute, Retrieved from http://www.krinstitute.org/assets/contentMS/img/template/editor/Rethinking\%20Ho using\%20(Full\%20Report)-\%20EN\%20Version.pdf

Kurniati, N. (2014). Pemenuhan Hak Atas Tanah Perumahan dan Permukiman, Padjajaran Jurnal Ilmu Hukum, 1(1), https://doi.org/10.22304/pjih.v1n1.a5

Leong, S. K. (2019, February 14), A Look at Every Aspect of Home Ownership, Retrieved from https://www.nst.com.my/property/2019/02/460076/look-every-aspect-homeownership

Mangeswuri, D. R. (2016), Kebijakan Pembiayaan Perumahan Melalui Fasilitas Likuiditas Pembiayaan Perumahan (FLPP), Jurnal Ekonomi \& Kebijakan Publik, 7(1), Retrieved from https://jurnal.dpr.go.id/index.php/ekp/article/view/410/314

MD Dahlan, N. H. (2011). Comparative Housing Sale and Purchase Agreements Under the Malaysia, Singapore, and New South Wales Housing Laws, Kedah: Universiti Utara Malaysia Press

Ministry of Housing and Local Government Malaysia. (2011). Housing in the New Millenium Malaysian Perspective, Retrieved from https://ehome.kpkt.gov.my/index.php/ pages/view/297

Mohd-Rahim, F. A., Zainon, N., Sulaiman, S., Lou, E., Zulkifli, N. H., Ayob, M. F. (2019). Factors Affecting the Ownership of Low-cost Housing for Socio-Economic Development Malaysia, Journal of Building Performance, 10(1), Retrieved from http://spaj.ukm.my/jsb/index.php/jbp/article/view/280

Mumin, M. H., \& Zainol, F. A. (2016). Causes of Abandoned Housing Projects in Malaysia The Stakeholders Views, Asian Journal of Knowledge Management, 3(1), Retrieved from http://www.asianikm.com/ejournal/index.php/aikm/article/view/15 
Nair, S., \& Sagaran, S. (2015). Poverty in Malaysia: Need for a Paradigm Shift, Institutions and Economics, 7(3), Retrieved from https://ijie.um.edu.my/index.php/ijie/article/view/ $\underline{5020 / 2858}$

National Housing Department Ministry of Housing and Local Government. (2016). National Housing Policy, Retrieved from http://rehdainstitute.com/wp-content/uploads/ 2016/03/nhp.pdf

Samad, D., Zainon, N., Mohd Rahim, F. A., Lou, E. (2017). Malaysian Affordability Housing Policies Revisited, Open House International, 42(1), https://doi.org/10.1108/OHI-01$\underline{\text { 2017-B0007 }}$

Sulaiman, N., Baldry, D., \& Ruddock, L. (2005). Can Low Cost Housing in Malaysia be Considered as Affordable Housing?, 12th Annual European Real Estate Society Conference, Dublin, Ireland, https://www.researchgate.net/publication/260036919 CAN LOW COST HOUSING IN MALAYSIA BE CONSIDERED AS AFFORDABLE HOUSI NG

Shuid, S. (2010). Low Income Housing Allocation System in Malaysia: Managing Housing Need for the Poor, 22nd IInternational Housing Research Conference, Istanbul, Turkey, Retrieved from https://core.ac.uk/download/pdf/300367374.pdf

Swee-Hock, S. (2007). The Population of Malaysia, Singapore: Institute of Southeast Asian Studies Publishing

The World Bank. (2019). Indonesia Economic Quarterly: Investing in People, Retrieved from https://openknowledge.worldbank.org/bitstream/handle/10986/33033/144221BA.pdf ?sequence $=5 \&$ isAllowed $=y$

Tighe, J.R., \& Mueller, E.J. (2013). The Affordable Housing Reader, Abingdon: Routledge

Tobi, S. U. M., Jasimin, T. H., \& Rani, W. N. M. W. M. (2020). Overview of Affordable Housing from Supply and Demand Context in Malaysia. IOP Conference Series: Earth and Environmental Science, https://doi.org/10.1088/1755-1315/409/1/012010

UN-HABITAT. (2008). The Role of Government in the Housing Market: The Experiences from Asia, Retrieved from https://unhabitat.org/the-role-of-government-in-the-housingmarket-the-experiences-from-asia

Woo, K. H. (2018). Affordable Housing Policy in Penang State of Malaysia, Global Encyclopedia of Public Administration, Public Policy and Governance, https://doi.org/10.1007/978-3319-31816-5 3671-1

Zaid, S., \& Graham, P. (2011). Low-Cost Housing in Malaysia: A Contribution to Sustainable Development?, $1^{\text {st }}$ International Postgraduate Conference on Engineering, Designing and Developing the Built Environment for Sustainable Wellbeing, Queensland, Australia, https://doi.org/10.13140/RG.2.1.2715.9120

Zamri, A. M. (2019). Homeownership Gaps Among the Middle Income Group in Malaysia, Journal of Science, Technology and Innovation Policy, 5(2), Retrieved from https://www.semanticscholar.org/paper/Homeownership-Gaps-among-the-MiddleIncome-Group-in-Zamri/9d85078e433deb7f13ed4dba5a00db5172babfea

Conflict of Interest Statement: The author(s) declares that the research was conducted in the absence of any commercial or financial relationship that could be construed as a potential conflict of interest.

Copyright: (C) HALREV. This is an open access article distributed under the terms of the Creative Commons Attribution 4.0 International License (CC-BY 4.0), which permits unrestricted use, distribution, and reproduction in any medium, provided the original author and source are credited.

Hasanuddin Law Review (Hasanuddin Law Rev. - HALREV) is an open access and peer-reviewed journal published by Faculty of Law, Hasanuddin University, Indonesia. 